\title{
The Effects of Chinese IFDI and OFDI on Industrial Upgrading from the Perspective of Regional Heterogeneity
}

Xiaomin $\mathrm{Li}$

Beijing Jiaotong University, China

*Corresponding author: Xiaomin Li, Master, 251757648@qq.com

\begin{abstract}
China is playing a more and more important role in the international division of labor as a dual role of host and investment country. This research identified the mechanism of FDI on Chinese industrial upgrading and analyzed the panel data of China's IFDI and OFDI from 2004 to 2014 with regression method using improved Chenery model to analyze the impact of IFDI and OFDI on China's industrial upgrading from an empirical perspective. Theoretical and empirical results have confirmed that IFDI and OFDI did play a role in promoting China's industrial upgrading. However there are large differences in various regions. The eastern coastal areas have obvious characteristics of export-oriented economy and OFDI started earlier and developed quickly .On the contrary, the development of OFDI in western regions has been relatively limited.
\end{abstract}

Key words: IFDI; OFDI; industrial structure upgrading; regional heterogeneity

\section{Introduction}

With the development of economic globalization, the economic ties between the countries of the world are becoming closer and closer. As an important carrier of industrial transfer, international investment will affect the industrial structure of a country, that is, foreign direct investment and foreign direct investment will affect the industrial structure of a country, both from the host country and the home country point of view. After 30 years of opening up to the outside world, China has become the world's largest international direct investment. China is playing a more and more important role in the international division of labor both as a host country and as an investment country, as foreign direct investment (IFDI) and foreign direct investment (OFDI) account for a growing proportion of the world.

At the same time, there are few articles on the impact of IFDI and OFDI on industrial structure upgrading in China. Moreover, China is a typical big country economy, and the characteristics of the big economy are regional heterogeneity (Cai Fang et al., 2009), the economic development of each region, the local government investment in scientific research costs and people's living standards Etc. There are many differences. The study of the impact of China's two-way FDI flows on industrial upgrading in the current situation and whether there are significant differences in different regions of China's development can help China explore how to combine the "introduction" and "going out" It is of great practical significance to formulate a new opening-up strategy to promote the optimization and upgrading of industrial structure and the sustainable development of macro-economy. 


\section{Literature review}

China also plays an increasingly important role in the international division of labor as host and investor countries. On this phenomenon, Janice, Han and Zou (2014) consider the impact of IFDI and OFDI on industrial upgrading. Industrial structure upgrade is more prominent; in the long run, China's two-way FDI to promote the upgrading of industrial structure have a role, but IFDI on the promotion of industrial structure is more significant effect, OFDI is the promotion of industrial structure rationalization more significant.

\subsection{IFDI and host country industrial structure upgrade}

How FDI affects the industrial development of the host country has positive and negative views. 2009). Foreign direct investment (FDI) has played a crucial role in the long-term development of the national economy (Camilla, 2002; Chen Jiyong and Sheng Yang Yi, 2009; Li Xiaozhong (2014) analyzed the direct and indirect effects of FDI on China's industrial structure, and concluded that the introduction of foreign capital is conducive to China's tertiary industry structure and the structural optimization of the secondary and tertiary industries, the technology spillover effect and export orientation of foreign capital of the business model to promote the upgrading of China's industrial technology structure and improve industrial structure. The results show that the impact of FDI incentive policies on industrial upgrading depends on two factors, one is between the host country and the home country Gap, the second is the host country industry market structure.

\subsection{OFDI and the home country's industrial structure upgrade}

In order to verify the specific effect of OFDI to promote the structural adjustment of domestic investment, domestic and foreign scholars have tried to use different methods to carry out empirical and empirical research. China is affected by the level of economic development and foreign direct investment, and the related research is later than abroad. Many scholars (Jiang Xiaojuan and Du Ling, 2002; Lupine, 2009; Yang Dakai, 2003) also believe that foreign direct investment can promote the upgrading of industrial structure. (2006) and Yan Min (2007), and compared the relationship between industrial restructuring and OFDI in Japan and Korea. It is found that there is a significant positive correlation between industrial structure change and OFDI in the two countries. The process of structure towards higher level is the process of OFDI release. (2008) and Huo Xin (2014) use the method of gray correlation analysis to conclude that China's OFDI has significantly promoted the optimization and upgrading of industrial structure, especially the industrial structure effect of OFDI in mining industry and manufacturing industry. Huo Xin (2014) constructed a VAR model to test the interaction between FDI and industrial structure optimization. He argued that there existed a long-term equilibrium relationship between FDI and industrial structure optimization in China, and in the short term both Out of each other to promote the development trend. 


\section{The impact of the mechanism}

\subsection{The impact of China's IFDI on the industrial structure of the mechanism}

(1)Affect the host country's demand structure and supply structure

Foreign direct investment will promote a country's demand structure. Such as the structure of consumption demand and the demand structure of production and consumption. Foreign direct investment in some of the emerging industries, to produce some new cost-effective products, will stimulate the lives of the host country people's needs, thereby driving the demand structure to enhance, to some extent, lead the consumer demand for consumption; the same time, foreign direct investment Industry, in order to maintain normal production operations will produce the demand for production, which will promote the corresponding forward and backward enterprise development, will lead to the production and consumption of the host country demand structure.

(2) Technology spillovers

The introduction of foreign capital will bring about an involuntary form of technology transfer - the emergence of technology spillovers, the establishment of subsidiaries in the host country by transnational corporations, the production of subsidiaries The development of technology will have an external economic effect on other local enterprises, Although investors tend to effectively protect their core technology, to avoid leakage, but the inevitable technical upgrading of the host country will bring some positive effects.

(3) Industry-related effects

The association effect has backward association and forward association. Backward linkages refer to the supply of raw materials, components, and services required by a local firm to a subsidiary of a multinational company. Forward link refers to the local enterprises by the host country for the production of multinational subsidiaries of its products sold in the market, semi-finished products or products, such as re-processing. Foreign direct investment leads to the adjustment of the industrial structure of the host country. In the multinational companies, driven by the international division of labor basically formed, and guide the changes in industrial structure around the world.

\subsection{The impact of China's OFDI on the industrial structure of the mechanism}

(1) Transfer of traditional industries, optimize the allocation of resources

A national industrial structure optimization and upgrading, is to make its various resources to achieve optimal allocation. In the course of economic development, there is bound to be a dominant industry in the country gradually lose the comparative advantage of the phenomenon, this time, this part of the industry should be transferred out of production factors, into a comparative advantage in the industry to make it bigger value.

(2) Industry-related effects, and promote industrial structure optimization

The FDI of the investment country promotes the optimization of industrial structure through the industrial linkage effect. When related industries enter the overseas market, in order to be 
able to compete in a competitive environment to seek a place, will inevitably lead to its domestic related products and services requirements, which will promote the development of domestic related industries and enterprises, and promote backward association and Forward-related enterprises to improve their technical level and service levels, and will also have a spillover effect, and promote the upgrading of the domestic industrial structure.

(3) The effect of industrial competition, and promote industrial structure optimization

The foreign direct investment of the investment country makes the enterprises that take the lead in entering the international market, in order to have a place in the competitive international environment, will continuously improve their own competitiveness, at the same time, this kind of improvement will bring pressure to the domestic industry enterprises, Which can lead to the domestic industry as a whole the competitive effect.

\section{Empirical Analysis on the Impact of Chinese Two - way FDI on Industrial Structure Upgrading}

\subsection{The model of the building}

Based on the modified form of "standard structure" of classic Chanel model, taking into account the short time of China's foreign direct investment, time and demographic factors have little influence on industrial structure, Therefore, in the model, the dummy variable $\mathrm{T}$ reflecting the time and the variable $\mathrm{N}$ reflecting the population factor are neglected. On the basis of the classic "standard structure" model, the paper takes into account the situation of using foreign capital and foreign investment, Asset investment FA, investment in research RD and residents consumption $U$ three control variables, the initial setting model is:

$\ln \mathrm{R}=\alpha+\beta_{1} \ln \mathrm{Y}+\beta_{2}(\ln \mathrm{Y})^{2}+\mu_{1} \ln \mathrm{IFDI}+\mu_{2} \ln \mathrm{OFDI}+\mu_{3} \ln \mathrm{RD}+\mu_{4} \ln \mathrm{FA}+\mu_{5} \ln \mathrm{U}+\varepsilon$

Table 1 Variables and their calculation methods

\begin{tabular}{|c|c|c|}
\hline The variable name & Variable symbol & Calculation method \\
\hline $\begin{array}{l}\text { Indicators of Industrial } \\
\text { Structure Upgrading }\end{array}$ & $\mathrm{SH}$ & $\begin{array}{l}\mathrm{R}=\mathrm{Y} 1+2 \mathrm{Y} 2+3 \mathrm{Y} 3, \quad \mathrm{Y} 1, \mathrm{Y} 2 \text { and } \mathrm{Y} 3 \text { is the first, } \\
\text { second and tertiary industries accounted for the } \\
\text { proportion of GDP }\end{array}$ \\
\hline Foreign direct investment & IFDI & FDI Flow(Million) \\
\hline $\begin{array}{c}\text { Foreign Direct } \\
\text { Investment }\end{array}$ & OFDI & Non - financial OFDI flows (Million) \\
\hline $\begin{array}{c}\text { Investment in Fixed } \\
\text { Assets }\end{array}$ & FA & Total Investment in Fixed Assets (Billion) \\
\hline Technology Progress & $\mathrm{RD}$ & Expenditure on research and testing (Billion) \\
\hline Consumer demand & $\mathrm{U}$ & Consumption level of residents (yuan) \\
\hline gross domestic product & $\mathrm{Y}$ & gross domestic product (Billion) \\
\hline The square of GDP & $\mathrm{Y}^{2}$ & The square of GDP (Billion) \\
\hline
\end{tabular}




\subsection{The source of data and processing}

Considering the availability and accuracy of the sample, this paper selects the panel data of 30 provinces and cities in China from 2003 to 2014 as the research object. The data are from China Statistical Yearbook and China Statistical Bulletin on Foreign Investment.

\subsection{Empirical results analysis}

According to Hausman test results, this paper uses the fixed-effect model to estimate, the regression results are shown in Table 2.

Table 2 Fixed effect model estimation results

\begin{tabular}{|c|c|c|c|c|}
\hline Explanatory variables & Nationwide & East area & Central Region & Western Region \\
\hline GDP & $\begin{array}{l}0.006 * * \\
(0.000)\end{array}$ & $\begin{array}{c}0.0017 * * * \\
(0.0001)\end{array}$ & $\begin{array}{c}0.0001 \\
(0.0008)\end{array}$ & $\begin{array}{c}0.0012 * * * \\
(0.0003)\end{array}$ \\
\hline GDPP2 & $\begin{array}{c}0.0012 * * * \\
(0.0000)\end{array}$ & $\begin{array}{c}-0.0002 * * * \\
(0.0019)\end{array}$ & $\begin{array}{l}-0.0011 \\
(0.0118)\end{array}$ & $\begin{array}{l}0.0009 * * \\
(0.0000)\end{array}$ \\
\hline IFDI & $\begin{array}{c}0.0014 \\
(0.2600)\end{array}$ & $\begin{array}{c}0.0270 * * * \\
(0.0000)\end{array}$ & $\begin{array}{l}0.0030 * * \\
(0.09710)\end{array}$ & $\begin{array}{l}-0.0061 \\
(0.5130)\end{array}$ \\
\hline OFDI & $\begin{array}{l}0.125 * * * \\
(0.0010)\end{array}$ & $\begin{array}{c}0.0009 * * * \\
(0.1020)\end{array}$ & $\begin{array}{l}0.002 * * \\
(0.0220)\end{array}$ & $\begin{array}{l}0.024 * * * \\
(0.0000)\end{array}$ \\
\hline FA & $\begin{array}{l}-0.0001 \\
(0.0071)\end{array}$ & $\begin{array}{l}-0.0001 \\
(0.0002)\end{array}$ & $\begin{array}{l}-0.0020 \\
(0.0008)\end{array}$ & $\begin{array}{l}-0.0009 \\
(0.0003)\end{array}$ \\
\hline $\mathrm{RD}$ & $\begin{array}{c}0.1210 \\
(0.0081)\end{array}$ & $\begin{array}{l}0.009 * * \\
(0.0036)\end{array}$ & $\begin{array}{l}-0.0019 \\
(0.0012)\end{array}$ & $\begin{array}{l}-0.0032 \\
(0.0006)\end{array}$ \\
\hline $\mathrm{U}$ & $\begin{array}{c}0.0048 * * * \\
(0.0408)\end{array}$ & $\begin{array}{c}0.0005 * * * \\
(0.0026)\end{array}$ & $\begin{array}{l}0.0007 * \\
(0.0007)\end{array}$ & $\begin{array}{l}0.0012 * * \\
(0.0004)\end{array}$ \\
\hline $\mathrm{C}$ & $\begin{array}{c}0.5221 * * * \\
(0.000)\end{array}$ & $\begin{array}{c}0.2727 * * * \\
(0.000)\end{array}$ & $\begin{array}{l}0.3541 * * \\
(0.0250)\end{array}$ & $\begin{array}{l}-0.8099 * \\
(0.0580)\end{array}$ \\
\hline $\mathrm{R} 2$ & 0.7019 & 0.8979 & 0.8620 & 0.8597 \\
\hline
\end{tabular}

Note: "**, "**" and $" * * * "$ indicate significant values at $10 \%, 5 \%$ and $1 \%$, respectively. Values in parentheses are standard deviations.

According to the regression results, IFDI has no obvious elastic effect on industrial structure heightening at the national level, OFDI promotes the upgrading of industrial structure significantly. At the regional level, IFDI in the eastern and central regions has a positive effect on the upgrading of industrial structure, $0.027,0.003$, respectively. That is to say, if the IFDI increases by $1 \%$, the level of industrial structure will increase by $0.027 \%$ and $0.003 \%$ respectively. The effect is more obvious in the east and the west has no obvious effect, possibly due to the small scale of IFDI in the western region. The impact of OFDI on the upgrading and upgrading of industrial structure is basically the same at the national level and the regional level, and it has obvious promotion effect. The effect of the increase of labor 
factor input on industrial structure upgrading and the high degree of the index is negative, because the average quality of the existing labor force in China is not high, and a large number of low-level industries in China still rely heavily on the advantages of demographic dividend survive. Consumer demand $U$ through the significance test and the symbol is positive, indicating that consumer demand and institutional factors have a positive impact on industrial upgrading, the more residents consumption, market economy more open, will better promote the adjustment and upgrading of China's industrial structure FA and R \& D investment RD regression coefficient are not significant, not in line with expectations, may be the majority of China's fixed asset investment is simply a simple expansion of production, and not very good to enhance the efficiency of resource allocation industries, and our country Of $\mathrm{R} \& \mathrm{D}$ investment is still relatively small, independent innovation capability is weak, can effectively promote the technological progress of related industries, and thus the role of China's industrial upgrading is not obvious.

\section{Suggestions}

First, China must pay attention to and guide the rational distribution of two-way FDI flow, speed up the mode of investment from the past "lenient, strict passive, passive" to "limited lead, active" transformation.

Second, continue to implement the IFDI development model from "quantity" to "quality" type, from "passive absorption" to "active selection". The government should continue to encourage and guide competitive enterprises to "go out", take a proactive approach to participate in international division of labor, give full play to OFDI on home country industrial structure to promote the effect.

\section{References}

1. A. Kanam, The Trade Trend of Wool Products in our Country, J. Review of Business and Economy. 13(1935)129-212.

2. B. Balassa, Trade liberalization and "revealed comparative advantage", J. The Manchester School. 33 (1965)99-123.

3. M. Blomstrom, F. Sjoholm, Technology Transfer: Does local Participation with Multinationals Matter, J. European Economic Review. 43 (1999) :915-923.

4. X Jing, Higher Industrial Structure and Economic Growth: An Empirical Analysis of the Yangtze River Delta, J. Journal of Nantong University (Social Science Edition). 3 (2005)57-62.

5. Z. Liu, The development effect of industrial upgrading and its motivation analysis, J. Journal of Nanjing Normal University (Social Science), 2(2000)3-7. 